\title{
POLITICS SYMPOSIUM
}

\section{Forecasting the 2017 German Elections}

\section{Introduction}

Bruno Jérôme, University of Paris II

T $\mathrm{n}$ the past 40 years, few papers have focused on voting models of German elections. Certainly, Kirchgässner (1977; 1991) or Rattinger (1991), developed VotePopularity (VP) functions predicting the German ruling parties' performance based on unemployment as a dominant economic variable. Furthemore, Jérôme, Jérôme-Speziari and Lewis-Beck (2001) explored the possibility of a "yardstick" competition between French and German economic votes.

However, until 2013, only a handful of models attempted to forecast German elections. Using Vote Functions, Jérôme, Jérôme-Speziari and Lewis-Beck (1998) initially developed forecasting model where the rate of unemployment and the popularity of the FDP were the main predictors.

This seminal model correctly forecasted the CDU/CSUFDP defeat. Thereafter, the same method has been successfully applied in 2005 and 2009 but failed in 2002 (Jérôme, Jérôme-Speziari and Lewis-Beck, 2002, 2005 and 2009). At last, in 2013 (see PS: Political Science \& Politics 46(03)) the authors opted for a SUR (Seemingly Unrelated Regression) model in order to predict both vote shares and suitable coalitions in a context where hinge parties (FDP and Greens) and new parties
(AFD) were increasingly key players. Here again, the incumbent's political and economic accountability (Key 1966) still plays a major role except for "peripheral" political parties.

On their side, Norpoth and Gschwend (2000; 2003) built a forecasting model where the desire for one of the main party's to provide the Chancellor predicts the election result. This model is known as the "Chancellor model" (Norpoth and Gschwend 2010; 2013). While Jérôme-Speziari and Lewis-Beck is rather retrospective, Norpoth and Gschwend's Chancellor model is mainly prospective. With a view to the next elections, the main predictor is the Chancellor support. Additionally, the model includes a second variable giving the partisan attachment and a third one reflecting the incumbent "fatigue," in other words, the cost of ruling. Such a configuration allows provision of forecasted vote shares and probabilities for each feasible coalition.

In this 2017 mini symposium, we welcome two new teams with alternative methods. Mark Kayser and Arndt Leininger follow the tradition of pooled time series models using disaggregated or regional data (see Rosenstone (1983) and Campbell (1992) in the US case or Jérôme, Jérôme and Lewis-Beck (1999) for French legislative elections). Their political economy Länder-based model underlines the relevance of regional political and economic data to predict the partisan structure of the next Bundestag and who could be the next Chancellor.

Lastly, Andreas Graefe presents a combined forecast based on the PollyVote research project initially launched in 2004

Table 1

Forecast Models in this Symposium

\begin{tabular}{|c|c|c|c|c|c|c|}
\hline Model & Authors & Method (Predictions' target) & (N) & Predicted Chancellor & Predicted coalition & $\begin{array}{l}\text { CDU/CSU - SPD } \\
\text { Vote share gap }\end{array}$ \\
\hline Pollyvote & Graefe A. & $\begin{array}{l}\text { Combined Forecasts } \\
\text { (Political parties) }\end{array}$ & - & - & - & +3.1 \\
\hline $\begin{array}{l}\text { Political Economy } \\
\text { Model }\end{array}$ & $\begin{array}{l}\text { Jérôme B., Jérôme V. } \\
\text { and Lewis-Beck M.S }\end{array}$ & $\begin{array}{l}\text { SUR Regression (Political } \\
\text { parties and coalitions) }\end{array}$ & $15 \times 6=90$ & Angela Merkel & CDU-SPD & +3.46 \\
\hline $\begin{array}{l}\text { Länder-based } \\
\text { Model }\end{array}$ & $\begin{array}{l}\text { Kayser M.A. and } \\
\text { Leininger A. }\end{array}$ & $\begin{array}{l}\text { Linear random coefficients } \\
\text { Model (Political parties) }\end{array}$ & 872 & $\begin{array}{l}\text { Doubts on Schulz } \\
\text { victory }\end{array}$ & & $+8.2 ;+11.6$ \\
\hline Chancellor Model & $\begin{array}{l}\text { Norpoth H. and } \\
\text { Gschwend T. }\end{array}$ & $\begin{array}{l}\text { OLS-Time series } \\
\text { (Coalitions - vote share } \\
\text { and probabilities) }\end{array}$ & 17 & Martin Schulz & $\begin{array}{l}\text { SPD-LINKE-GREENS } \\
\text { SPD-GREENS-FDP } \\
(\mathrm{Pr}=83 \%) \text { each }\end{array}$ & -0.9 \\
\hline
\end{tabular}


(Cuzàn, Armstrong, and Jones 2005) to forecast US elections. In the German Case, a first attempt has been made during the 2013 elections. Gathering predictions issued from polls, prediction markets, experts and models, and treating them on average, PollyVote provides vote-share forecasts for each German party.

If German general elections were held in early March, three models out of four predict the CDU/CSU could win despite a significant loss of votes compared with 2013 (see table 1). However, Norpoth and Gschwend are dissonant to the extent that they forecast a $83 \%$ chance of winning for a coalition (red-red-green or "Traffic Light") led by Martin Schulz.

On balance, the Grand Coalition could be reappointed but Angela Merkel seems to be on borrowed time.

\section{REFERENCES}

Campbell, James E. 1992. "Forecasting the Presidential Vote in the States." American Journal of Political Science 36 (2): 386-407.

Cuzán, Alfred G., J. Scott Armstrong, and Randall J. Jr. Jones. 2005. "How We Computed the PollyVote." Foresight: The International Journal of Applied Forecasting 1 (1): 51-52.

Graefe, Andreas. 2015. "German Election Forecasting: Comparing and Combining Methods for 2013." German Politics 24 (2): 195-204. doi: 10.1080/09644008.2015.1024240.

Gschwend, T. and H Norpoth. 20oo. "Soll und Haben: Die deutsche ählerschaft rechnet mit den Parteien", ab. S: 389-409 in: Markus Klein, Wolfgang Jagodzinski, Ekkehard Mochmann und Dieter Ohr (Hg.): 5o Jahre Empirische Wahlforschung in Deutschland. Entwicklung, Befunde, Perspektiven, Daten. Wiesbaden: Westdeutscher Verlag.
Jérôme, Bruno, Veronique Jérôme-Speziari, and Michael S. Lewis-Beck. 1998 "prévisions politico - économiques et élections législatives allemandes de septembre 1998." Cheminement du futur, Le Figaro économie, July 10.

_. 1999. "Polls fail in France, forecasts of the 1997 Legislative election." International Journal of Forecasting 15 (2): 163-74.

- 2001. "Evaluation économique et vote en France et en Allemagne." l'Opinion européenne 2001, Presses de sciences Po., avril, p. 101-122.

- 2002. "Pourquoi Stoiber peut (encore) gagner." Le Figaro, September 18, p.17.

- 2009. ElectionScope website. http://www.electionscope.fr/prévisionélectorale/elections-législatives-allemandes/législatives-2009/

- 2013. "A political-economy forecast for the 2013 German elections : who to rule with Angela Merkel ?" PS : Political Science \& Politics 46 (3): 479-8o.

Jérôme-Speziari, Veronique. 2005. "Prévision des élections allemandes de 2005 : vers une grande coalition." Interview, BFM radio, September.

Key, V. O. 1966. The Responsible Electorate, New York, Vintage.

Kirchgässner, Gebhard. 1977. "Wirschaftslage und wähleverhalten”, Politische Vierteljahresschrift, 18:510-536.

- 1991. "Economic conditions and the popularity of the West Germany parties, before and after the 1982 government change." In Economic and Politics, the Calculus of Support, 103-22. Ann Arbor, MI: University of Michigan Press.

Norpoth, Helmut and Thomas Gschwend. 2003. "Against All Odds? The Red-green Victory." German Political Studies 21 (1): 15-34.

_. 2010. "The Chancellor Model: Forecasting German Elections." International Journal of Forecasting 26 (1): 42-53.

—. 2013. "Chancellor Model Picks Merkel in 2013 German Election." PS: Political Science \& Politics 46 (3): 481-82.

Rattinger, Hans. 1991. "Unemployment and elections in West Germany." In Economic and Politics, the Calculus of Support, 49-62. Ann Arbor, MI: University of Michigan Press.

Rosenstone, Steven J. 1983. Forecasting Presidential Elections. New Haven: Yale University Press.

\section{SYMPOSIUM CONTRIBUTORS}

Bruno Jérôme is associate professor in the department of economics at the University of Paris 2 and member of the Law and Economics Center of Paris 2. His interests are political economy, public economics, election forecasting, European economics and institutions. His most recent books are Analyse Economique des Elections (Economica); (2010 coauthored with Veronique Jerome-Speziari) and Villes de gauche, villes de droite : Presses de Sciences Po (Forthcoming, 2017 co-authored with Richard Nadeau, Véronique Jérôme-Speziari and Martial Foucault). He may be reached at bruno.jerome@gmail.com.

Véronique Jérôme-Speziari is associate professor in the department of management at the University of Paris Sud 11 and member of the Paris 2 Laboratory of Management. Her interests are political economy, public economics, election forecasting, political marketing, and nonverbal communication. Her most recent books are Analyse Economique des Elections (Economica); (2010, co-authored with Bruno Jerome) and Villes de gauche, villes de droite: Presses de Sciences Po, La Victoire Electorale ne se décrète pas! (Economica); (2017, co-authored with Bruno Jerome). She may be reached at veronique.jerome@ gmail.com.
Thomas Gschwend is professor and chair of Quantitative Methods in the Social Sciences at the Department of Political Science, University of Mannheim (Germany) where his research focuses on comparative politics, judicial politics, public opinion, political psychology as well as political methodology. His most recent English book publications are Research Design in Political Science: How to Practice What They Preach (Palgrave Macmillan, 2011; coedited with Frank Schimmelfennig), and Strategic Voting in Mixed-Electoral Systems (SFG Elsevier 2004). He is recipient of the Gosnell Prize for Excellence in Political Methodology awarded by the APSA Political Methodology Section. He may be reached atgschwend@uni-mannheim.de.

Andreas Graefe is the endowed Sky Research Professor at Macromedia University Munich and a research fellow at the Tow Center for Digital Journalism at Columbia University. As the leader of the PollyVote project, Andreas has done extensive validation work on election forecasting methods and has developed several election forecasting models. He may be reached at graefe.andreas@gmail.com.

Helmut Norpoth is professor of political science at Stony Brook University. He is coauthor of The
American Voter Revisited and has published widely on topics of electoral behavior. His book, Commander in Chief: Franklin Roosevelt and the American People, is forthcoming. He can be reached at helmut. norpoth@stonybrook.edu and @primarymodel16.

Michael S. Lewis-Beck is F. Wendell Miller Distinguished Professor of Political Science at the University of Iowa. His interests are comparative elections, election forecasting, political economy, and quantitative methodology. Professor Lewis-Beck has authored or coauthored over 260 articles and books, including Economics and Elections, The American Voter Revisited, French Presidential Elections, Forecasting Elections, The Austrian Voter, and Applied Regression. He may be reached at michaellewis-beck@uiowa.edu.

Mark Kayser is professor of applied methods and comparative politics at the Hertie School of Governance in Berlin. His research primarily focuses on elections and political economy. He may be reached at kayser@hertie-school.org.

Arndt Leininger is a research fellow at the University of Mainz. His research primarily focuses on direct democracy and elections. He may be reached at leininger@politik.uni-mainz.de. 